\title{
ON THE DARTFORD HEATH GRAVEL AND ON A PALÆOLITHIC IMPLEMENT FACTORY.
}

BY R. H. CHANDLER aNd A. L. LEACH, F.G.S.

\author{
[Read Jamuary 5th, 1912.]
}

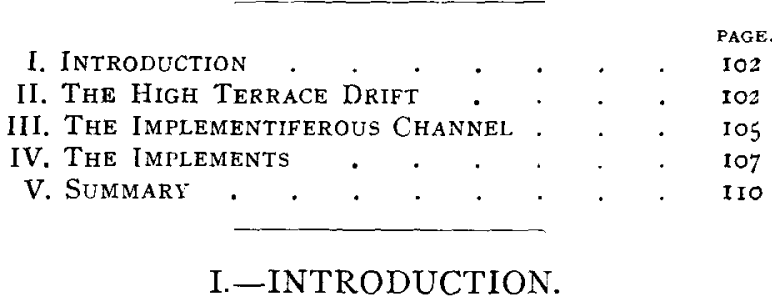

$0^{N}$ $\mathrm{N}$ the occasion of the Excursion to Dartford Heath, in March, I9II, we drew attention to a deposit (somewhat later in date than the normal Dartford Heath Gravel) from which we had obtained Palæolithic flakes and implements, and in the Report* we suggested that a flaking-site existed in this locality, but we were not then able to make more than a brief reference to the implementiferous section. We now propose to describe the deposit in detail, and to collect the stratigraphical and other evidence from which the age of the implements may be inferred.

\section{II.-THE HIGH TERRACE DRIFT.}

Between Crayford, Bexley and Dartford a broad gravelspread, at least two square miles in area, forms the high ground of Dartford Heath, and eastward of the Darent smaller patches of Drift Gravels extend through the Brent; Horn's Cross, and Stone, to the well-known deposits at Galley Hill and Milton Street, Swanscombe. By an examination of its pebbles (other than flint) the Dartford Heath Gravel can be shown to contain a large amount of material derived from various high-level Driftsfluviatile and glacial-in the upper part of the Thames basin. We have recorded elsewhere ${ }^{\prime}$ many of these non-local constituents, among which various igneous rocks, Bunter quartzites, Carboniferous (crinoidal) and other cherts are noteworthy. A Jurassic chert, containing the sponge Rhaxella perforata, and known as Arngrove Stone in the neighbourhood of Brill, where it is found

\footnotetext{
* Proc. Geol. Assoc, vol. xxii, p. I7r.
}

t Ibid., vol. $\times$ X (1907), p. I22. 
in the Corallian rocks, ${ }^{*}$ occurs quite abundantly in Wansunt pit, and indicates very clearly the influence of the Thames in the formation of the deposit. $\dagger$

N.

Creyford

Rly. Station

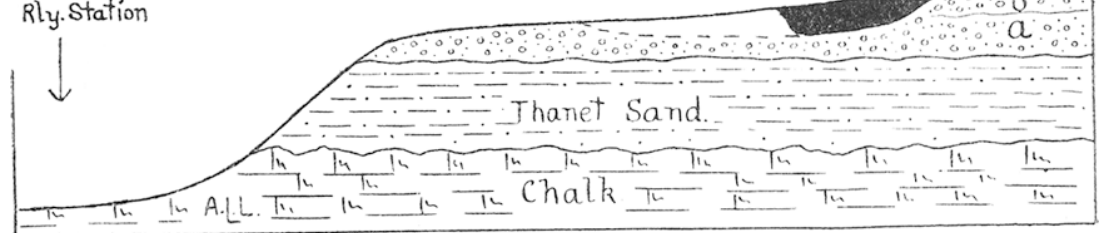

Fig, 5.-Section from Crayford Station to Dartford Heath, showing THE RELATION OF THE IMPLEMENTIFEROUS CHANNEL TO THE DARTFORD Heath Gravel ( $a$ and $b$ ).- $-A$. L. Leach.

The proved extent of the channel is shaded black.

The finest sections of the Dartford Heath Gravel are shown in the huge pits at Wansunt, where the Drift, upwards of $40 \mathrm{ft}$. thick, is composed of two distinct members (see Fig. 5):

Gravelly soil .

(b) Red, loamy gravel, distinguished by its even bedding and deep orange or red colour, containing thin lenticular bands of loam or brick-earth.

(a) Clean yellow sands and loose gravel, characterised by strong current - bedding, with irregular ferruginous bands, frequently cemented into strong "iron-pan" at the base . . .
I to 2

25 to 30

As a whole the gravel is well water-worn, and contains very few of the large, slightly-abraded flint nodules which occur commonly in lower-level gravels at Crayford and Dartford. We have reason to think that the bulk of the non-local rocks are associated with the lower false-bedded gravel, and that the distinction drawn between the two members corresponds to an important change in the conditions of deposition, but this point need not be considered further at present.

The Dartford Heath deposits include also beds of valuable brick-earth resting in hollows upon the gravel, but little of this material now remains. The whole mass of sands, gravels, and loams seems almost destitute of fossils; Prestwich mentions Rhinoceros, Mammoth, and Cyrena fuminalis, but the exact

* E. T. Newton. "Note on Specimens of Rhaxella-chert, etc." Proc. Geol. Assoc., vol. $x x$, p. 127.

+ Some pebbles of Rhaxella-chert were noted amongst specimens from the gravels ot the River Lea, exhibited by the Rev. Dr. A. Irving during the excursion to Bishop's Stortford in Igrr (A. L. L.). 
localities are not recorded, and a few years ago a leg bone of Mammoth (?) was reported to have been found in Wansunt pit. We are not acquainted with any other discoveries of Pleistocene fossils, and, although we have searched the gravel closely during the last five years, we have not obtained any traces of shells or bones.

The applicability of the term "High Terrace" Drift to these deposits must now be considered. In describing the roo-feet terrace, Mr. T. I. Pocock * has remarked: "Throughout the forty miles from Staines to Grays the upper terrace maintains the same average height above the sea-level. Its under-surface varies from place to place, but generally speaking it is at about the roo-foot contour line near its margin."

The base-level of the Dartford Heath Gravel lies, so far as our observations show, within the limits go-too ft. above O.D., being thus in agreement with the level of the Milton Street gravel which is described by Messrs. Kennard and Hinton $\dagger$ as the roo-foot terrace. The gravels extending from Galley Hill (Swanscombe) to Dartford Heath were regarded by Mr. F. C. J. Spurrell as "parts of one original stretch of deposits," + and the close agreement in base-level of all these patches $(e . g .$, Milton Street, Dartford Brent, Dartford Heath) must, we think, be taken as evidence of their origin as one Terrace of River Drift, their present isolation being brought about by the later dissection of the Terrace by the deep channels of the Cray, Darent, and smaller streams.

The separation of the Dartford Heath Gravel as "the highest terrace of the Thames," in distinction to the High Terrace (roo-foot Terrace) of Swanscombe, was suggested by Messrs. Kennard and Hinton, $\$$ and is adopted by Mr. H. B. Woodward, If but it appears to be based on a mistaken estimate of the height of the former gravel, which has been variously stated as 130,136 , I50, $160 \mathrm{ft}$. above O.D. The height-1 $36 \mathrm{ft}$. -is that of the highest point mapped on the Heath ; the base-level of the gravel is identical with that of Milton Street, viz., 90-100 ft. above O.D., and, in face of this agreement, the distinction drawn between them cannot, we think, be maintained. If any separation is to be made between the Dartford Heath and Swanscombe (Milton Street) gravels it must be on quite other grounds than any supposed difference in their base-levels.

Before leaving this part of the subject we must remark that some uniform scheme of recording the "heights" of graveldeposits is much to be desired. Mr. H. B. Woodward states that "the elevations are usually reckoned from the surface of the

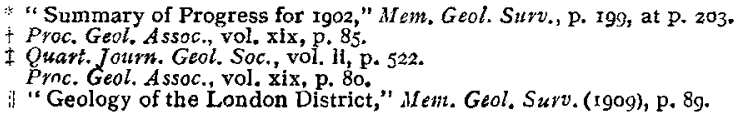


ground, not from the platform on which the deposits rest." * Many drift geologists certainly do not follow this plan but record the base-level ; others again, unfortunately, do not explain whether the given figures refer to base-level, summit-level, or average-level. It may be admitted that for many thin gravelspreads the difference between their base- and summit-levels may be unimportant, and, again, that in many cases the baselevel is difficult to determine; but neither of these points applies to the gravels under consideration. We would suggest as the most useful data for the comparison of gravel-levels-the range of the base, the maximum thickness of the deposit, and the highest point or summit-level.

Thus for the Dartford Heath gravel:

Range of base, 90-100 ft. above O.D.

Maximum thickness, $40 \mathrm{ft}$.

Highest point, $136 \mathrm{ft}$. above 0.1 .

\section{III.-THE IMPLEMENTIFEROUS CHANNEL.}

Towards the close of I910 the upper red gravel in the northeastern part of Wansunt pit was observed to end suddenly in an irregular buried slope against which lay clayey beds differing greatly from the normal gravel. Some hundreds of tons of clay were removed, and during the progress of this work many flakes and implements were obtained by the workmen, but we did not learn of these discoveries until January, I9II, when we found a few flakes and an implement of Palæolithic form lying in the pit. The sharp unabraded edges of these flakes led us to think they were from the clay. The pit was visited during working hours, many flakes and a few implements were obtained from the workmen, and the finders were closely questioned (individually as far as possible) as to the circumstances of the discovery of the implements. All agreed in stating that the worked flints were from the "clay" in which a "nest" of flakes had been found and several "spear-heads." We carefully searched the clay and obtained a few flakes in situ, and in a loam connected with the same deposit we found a Palæolithic implement broken and highly patinated. Subsequently Mr. Joseph Davies, of Dartford Heath, who unknown to us had been watching the excavations and had obtained many implements and flakes, kindly allowed us to examine his collection. His observations confirmed the workmen's statements and, with the evidence of the flakes found by us in place, furnished satisfactory proof of the occurrence of the implements in the deposit termed "clay" by the workmen to distinguish it from the commercially valuable

$$
\text { * Op. cit., p. } 87 \text {. }
$$


gravel. As the excavation proceeded we were able to separate the "clay" into three deposits, distinct in character and arrangement from the Dartford Heath Gravel and clearly somewhat later in date, since they lay in a channel eroded in the normal High Terrace gravel.

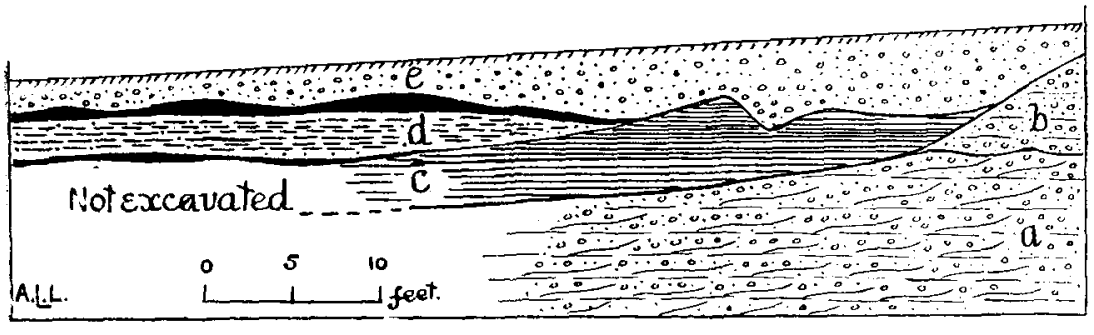

Fig. 6.-Section Ioo Yards N.N.E. Of EdiTh Villas, DarTford HЕATH. - A. L. Leach. $\left.\begin{array}{l}\text { b. Upper red gravel } \\ \text { a. False-bedded gravel }\end{array}\right\} \begin{gathered}\text { Dartford } \\ \text { Heath } \\ \text { Gravel. }\end{gathered}$ $\left.\begin{array}{l}\text { b. Upper red gravel } \\ \text { a. False-bedded gravel }\end{array}\right\} \begin{gathered}\text { Dartford } \\ \text { Heath } \\ \text { Gravel. }\end{gathered}$
e. Unstratified loamy gravel Deposits in the d. Stratified loams and clay Implementiferous c. Dark clay. Channel.

The southern bank of this channel, dipping sharply ( $16^{\circ}$ approximately) northward can be traced for fully $\mathbf{I}, 000$ feet along the northern edge of Wansunt pit, at about I $20 \mathrm{ft}$. above O.D., and here and there small loam-choked trenches indicate the entry of former small tributaries draining from the broad gravel-spread to the sotth. The width of the channel towards the north cannot be definitely stated, but it did not exceed and probably was much less than 300 yards. Its eastward extent is also unknown.

The deposits in the channel were as follow: At the bottom lay a stiff brown clay $(c)$ with thin layers of sandy gravel and scattered pebbles. Flakes occurred here and lumps (apparently chipped) of fresh-looking flint bearing on the fractured surfaces a dull polish resembling the gloss produced on flints exposed to the gentle friction of silt on the foreshore of the Thames. A piece of bone too much decayed to be removed was seen lying in this clay. In the overlying well-bedded loam or brickearth $(d)$ there were no pebbles, but here most of the flakes and implements were found, mostly below certain lenticular patches of blue silty clay interbedded with the loam. A few fragments of teeth from this deposit were submitted to Mr. E. T. Newton, who remarks: "One is a fragment of the inner part of an upper grinder of Horse (Equus caballus); a second piece is Bos, and a third is probably Bos. I use Bos in its widest sense; these may be Bos taurus, var. primigenius or Bos bison." 
Proc. Geol. Assoc., vol. XXIII.

Plate 16.

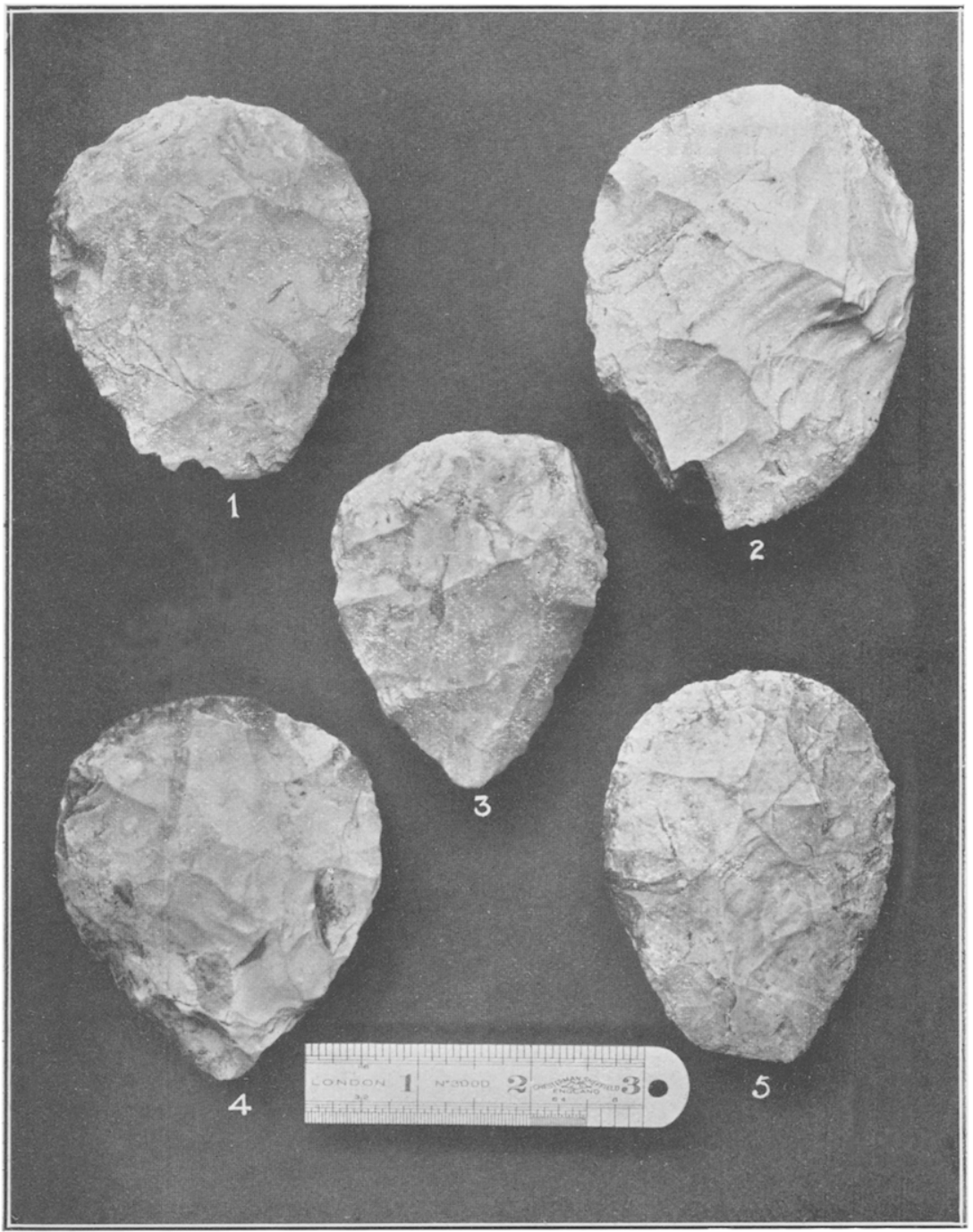

Photo by $E$. C. Youens.

Flint Implements of St, Acheul Forms, from the Channel, Waisunt Pit, Dartford Heath. 
The uppermost deposit in the channel, an unstratified loamy gravel $(e)$ composed probably of subaerial detritus from the higher ground to the south, rests upon an irregular surface of the underlying beds.

The following explanation of the observed facts is suggested. Stratified clay and loams were deposited in a channel eroded in the High Terrace gravel by a stream flowing approximately along the northern edge of the present Heath, at some period when the old gravel-spread had become sufficiently dry to be habitable but while its surface had not been greatly raised above the then level of the rivers by which it had been laid down. Whether the Wansunt channel was excavated by a tributary of the Pleistocene Thames or of the Cray or Darent is immaterial. The bank of this stream was the site of a Palæolithic implement factory, but beyond the imperishable implements and flakes and the fragments of teeth. the remains perhaps of animals killed for food, no indications of human occupation have yet been observed. Eventually the stream found a new course, the old channel was deserted and masses of sand and gravel swept down from the higher ground immediately south of the channel, disturbed the surface of the old stream deposits (see Fig. 6) and completed the in-filling of the channel. In this last stage the movement of the drifting sand and gravel was possibly promoted by heavy rains or by the thawing of masses of snow, when the gravel-spread had no protective covering of vegetation. The deposits in the channel at Wansunt indicate a pause in the general elevatory movement which intervened between the formation of the High (Dartford Heath) and Middle (Crayford) Terrace Drifts ; but in point of age they are undoubtedly much more closely related to the former than to the Crayford deposits.

\section{IV.-THE IMPLEMENTS.}

The following are the only satisfactory records of implements from the normal Dartford Heath Gravel with which we are acquainted :

I. An implement (now in the British Museum) found by Mr. F. C. J. Spurrell at a depth of $8 \mathrm{ft}$. in the gravel. (Probably, therefore, in the red gravel).

2. An implement obtained by us in Wansunt pit. It came probably from the red gravel, and closely resembles Spurrell's in size and form, but is fresher in appearance.

3. A few small implements and flakes, all quite white, found by Mr. J. Davies near the base of the red gravel (one shown in Pl. 18, Fig. I).

4. A rough and much battered implement found by us in the 
lower gravel in Wood's Pit. It is obviously much older than the gravel (Pl. 18, Fig. 2).

5. A roughly flaked implement, slightly abraded, from the last locality (Pl. I8, Fig. 3).

We have seen other palæoliths from Dartford Heath, but in the absence of details of their discovery we can only state that they resemble well-known forms. The materials are too scanty for the description of a "type," but it must be admitted that those numbered 1,2 , and 3 above are distinctly unlike the well-known Swanscombe forms.

With regard to the channel implements, all the essential details of their occurrence are known, and, as we have seen about 60 implements and perhaps 200 flakes, the group is sufficiently large to repay examination.

We will deal first with their mineral condition. The Wansunt palæoliths (flakes and implements) look remarkably fresh; their edges are sharp, none are rolled or abraded (except a few which are obviously derivative), and their surfaces are not appreciably stained. On closer examination most of them show:

a. Spots and streaks of iron and manganese oxides.

$b$. White spots and pale ramifying streaks due to incipient patination.

c. Spots and patches (nearly a square inch in one case) of a brilliant siliceous glaze on the flaked surfaces.

d. Patches of ferruginous sand cemented firmly into the crevices.

e. A slight polish or gloss on the flaked surfaces.

It is not contended that these characters establish the Palæolithic age of the implements, but they certainly prove them to be not recent, and to that extent corroborate the evidence of their shape and of the conditions of occurrence. Many specimens from the Palæolithic site at "Baker's Hole" (the Southfleet chalk-pit), Northfleet, and from the Crayford brick-earths, are equally fresh in general appearance. We conclude that the flakes were struck off and the implements were made very close to where they were found, because :

a. Implements and flakes are unabraded.

b. At least one "nest" of flakes was found such as would result from flaking on the spot.

c. Some of the flakes can be fitted to re-form parts of the original nodules. By combining five large flakes in this way one nodule has been partly rebuilt, and, belonging to the same block, there are at least a dozen other flakes. Several groups of flakes belonging to other characteristically banded or coloured nodules have been obtained.

Among the implements from the channel deposits the types of St. Acheul and Le Moustier are represented, with a few which fall into neither group. 
Proc. Geol. Assoc., vol. XXIII.

Plate I 7 .

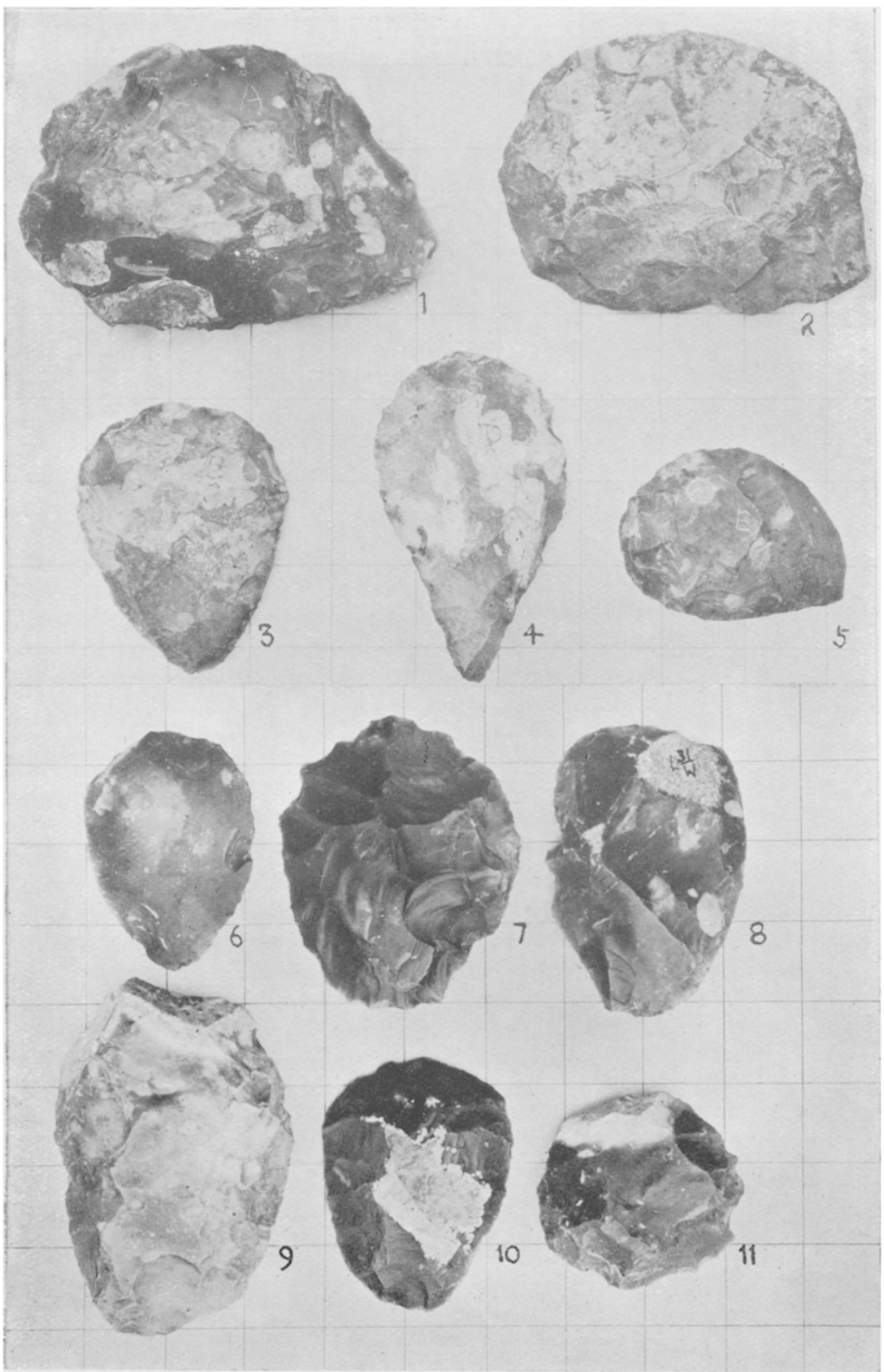

Photo by E. C. Youens.

Flint implements from the Channel, Wansunt Pit, Dartford Heath. (The background is ruled in one-inch squares.)

To face page ro8. 
St. Acheul Forms. - About one-third of the implements form a group of finely-worked oval and ovate or cordate implements, agreeing closely amongst themselves in size and shape, and differing clearly from the types of Chelles and Le Moustier. This group, if any, is distinctive of the implementiferous channel, and might be termed the "Wansunt group." So distinctive is the form that when we examined Mr. W. M. Newton's large collection we detected several which by mistake had been placed amongst Swanscombe implements. Their surfaces exhibit patination in various stages from blue-grey films to complete bleaching; one finely-worked specimen in Mr. W. M. Newton's collection has acquired a pure white porcellaneous surface. (See Pl. 16, Figs. 1, 2, 3, 4, 5 ; Pl. 17, Figs. 3, 9.)

Some of the implements and flakes in this group have the twisted edge (like an $S$ reversed) which has been noted on implements from several localities. ${ }^{*} \dagger$

Le Moustier Forms. - Four flakes finely worked on the convex face; the bulb face shows little or no trimming. (Pl. I7, Figs. 6, 8 , 10.) These oval flakes contrast remarkably in outline with the long, slender Le Moustier forms from the Crayford brick-earths.

Unclassified Fornis.-These include two acutely pointed pear-shaped implements (Pl. I 7, Fig. 4) which resemble some of the sharp-rimmed Swanscombe (Milton Street) types, but are more finely worked and without the heavy butt. There are also five discoidal implements roughly flaked (Pl. I7, Figs. 7 and I I), and three unsymmetrical implements with one straight edge and one highly convex cutting edge (Pl. 1 7, Figs. 1, 2, and 5).

The points to be emphasised are the occurrence of (x) a few implements of the forms characteristic of Le Moustier, (2) small groups of implements of unusual forms, (3) a large group of implements of St. Acheul forms. The series comprises a mixture of St. Acheul and Le Moustier forms, but the latter are rare and the former are represented by small specimens such as are associated with the later part of the period. The implements appear therefore to belong to the close of the St. Acheul stage and the dawn of that of Le Moustier. This is in agreement with the stratigraphical evidence upon which the deposit was assigned to the interval between the High (Swanscombe, St. Acheul) and Middle (Crayford, Le Moustier) Terrace deposits. A similar association of Le Moustier forms with older implements has recently been described by Mr. Reginald Smith, + who considers that near Baker's Hole, Swanscombe, there existed a factory of Le Moustier implements upon which older forms p. 25 .

* See British Museum "Guide to the Antiquities or the Stone Age," etc., Fig. I5,

+ I consider the twist on flakes due to the flint and not to workmanship. $-R$. H. C.

1 "A Palæolithic Industry at North leet, Kent." Archaologia, vol. Ixii (1911), p. 515.

Proc. Geol. AsSoc., Vol. XXIII, PART 2, 19i2.] 
were swept down in a deposit correlated by Mr. Clement Reid with the Coombe Rock.

By its level (about $45 \mathrm{ft}$. above O.D.) the Baker's Hole (Southfleet pit) factory should be later in date than the Wansunt channel deposits, and the condition of the implements supports this view. The St. Acheul implements of Baker's Hole nearly all show signs of derivation from an older or higher level, but at Wansunt they are (with one doubtful exception) quite fresh and unworn. Some of the Le Moustier implements of Wansunt differ from the Baker's Hole Le Moustier forms, and agree with the cave type, in showing secondary working after having been struck from the core.

\section{V.-SUMMARY.}

I. The Dartford Heath Gravel belongs to the " Ioo-foot" or High Terrace, and is equivalent to that of Swanscombe (Milton Street).

2. The implementiferous channel at Wansunt was eroded after the deposition of the Dartford Heath Gravel, and Palæolithic implements were made on its bank.

3. The forms typical of St. Acheul and Le Moustier are represented amongst the contemporaneous implements of the channel, and from their character and the stratigraphical evidence the implementiferous deposit appears to be related to the late St. Acheul or early Le Moustier period.

We desire to record our thanks to Mr. Joseph Davies and to Mr. W. M. Newton, who kindly allowed us to make full use of their collections; to Mr. E. T. Newton, who examined the teeth; and to Mr. Reginald A. Smith, to whom we are indebted for much assistance in the description of the implements.

\section{EXPLANATION OF THE PLATES.}

Plate i6.

[Implements from the Channel, Wansunt Pit ; all of St. Acheul forms, finely worked and unabraded.]

Fig. I. Implement of grey flirt, point broken.

Fig. 2. Implement with bluish patina, point broken.

Fig. 3. Implement worked from a grey gravel flint; cortex on butt.

Fig. 4. Implement of grey flint, edge twisted.

Fig. 5. Implement of grey flint, point broken.

\section{Plate i 7.}

[lmplements from the Channel, Wansunt Pit.]

Fig. I. Implement roughly worked from chalk-flint nodule ; shows cortex in places. (Cf. Figs. 2 and 5 for form.)

Fig. 2. Finely worked in grey and black flint.

Fig. 3. Ditto. St. Acheul form. 


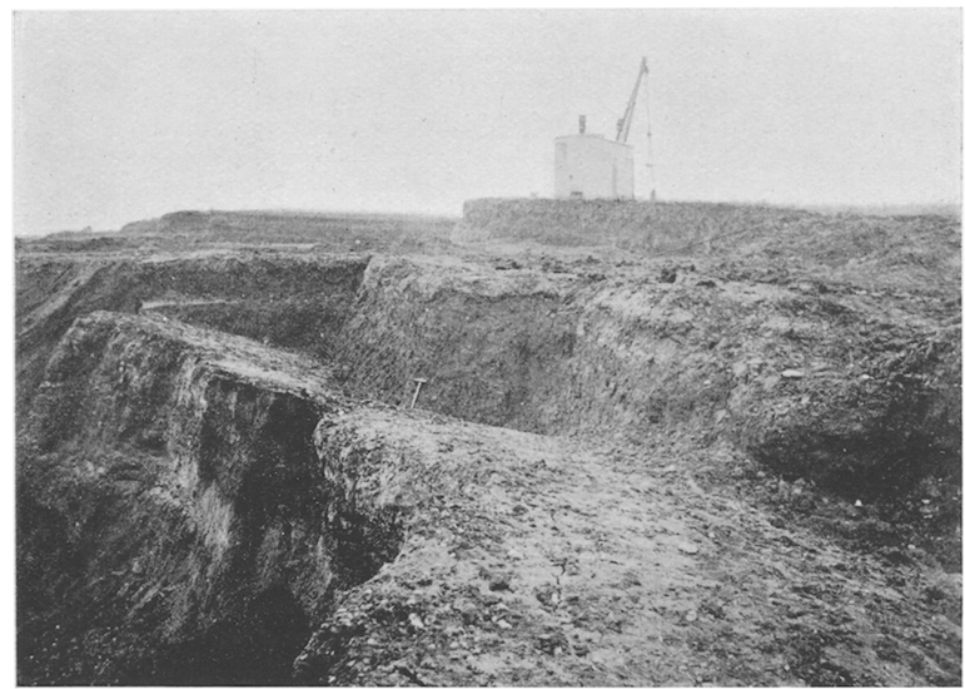

Photo by R. H. Chandler.

A.-View of the Channel, Wansunt Pit, Dartford Heath, LOOKING WESTWARD.

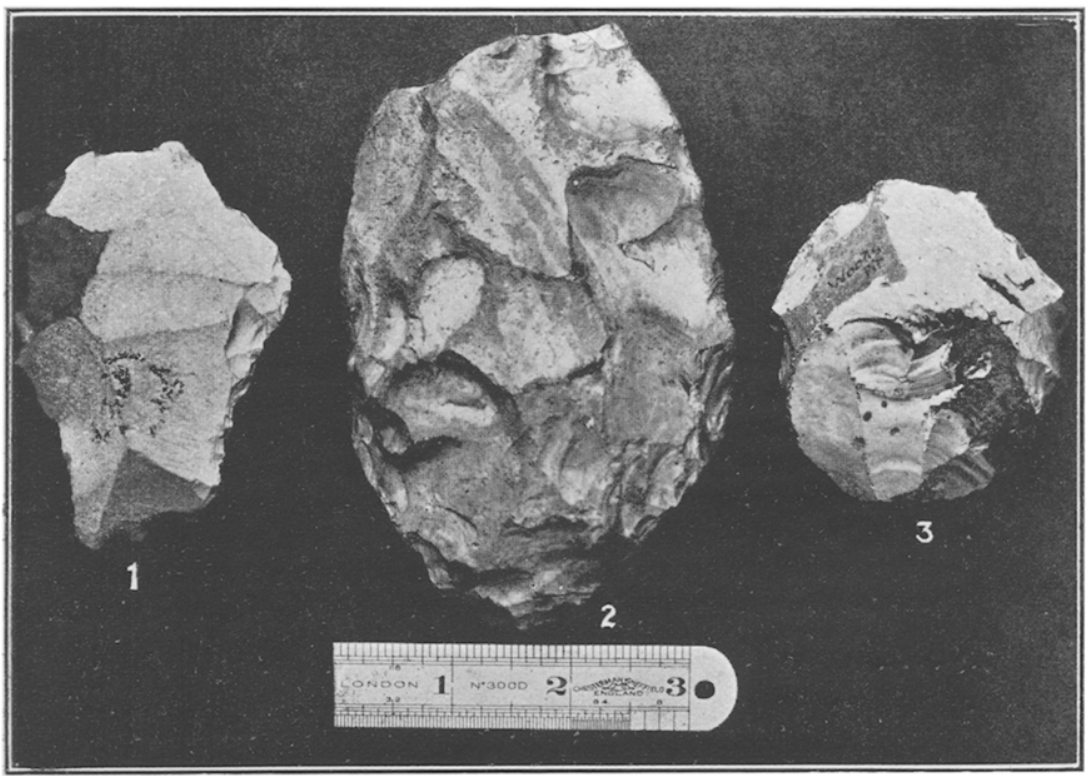

Photo by E. C. Youens. B.-Flint lmplements from Dartford Heath.

To face page п10. 
Fig. 4. Finely worked implement of yellowish flint. St. Acheul form.

Fig. 5. Finely worked implement of grey flint.

Fig. 6. Le Moustier type. Struck from black chalk-flint nodule; edge finely trimmed, bulb face shows no working. The photograph shows the smooth bulb face; on the reverse face a patch of cortex remains. (Cf. Figs. 8 and ro.)

Fig. 7. Discoidal implement worked from fresh black flint. (Cf. Fig. Ir.)

Fig. 8. Le Moustier type. Finely worked round curved edge. Flaked from a dark gravel flint.

Fig. 9. From a grey gravel flint, roughly worked implement. Cortex on butt.

Fig. 10. Le Moustier type. Flaked from a black chalk-flint nodule. The bulb has been dressed off and the edges worked.

Fig. I1. Roughly flaked discoidal implement made from yellow gravel fint. Cortex on butt.

\section{Pi.ATE I8.}

A. Photograph (looking westward) of the channel in which the implements were found. The hammer stands on the floor of the channel; its head rests against the clay (Fig $6 \mathrm{c}$ ) in which worked flakes and a fragment of bone were seen in sital. The djagram, Fig. 6 , gives a reverse view of this channel.

B. Fig. I. From the red gravel, Wansunt Pit. Roughly worked, bleached. Fig. 2. From the false-bedded gravel, Wood's Pit, Dartford Heath. Roughly worked, bleached, worn and stained. Chelles type. Derived.

Fig. 3. Same locality. Roughly worked, worn and bleached. Probably derived. 